\title{
First report of the genus Heterorhabditis (Nematoda: Heterorhabditidae) from continental Portugal
}

\author{
V. VALADAS ${ }^{1, *}$, P. VIEIRA $^{1}$, S. OLIVEIRA ${ }^{2}$, M. MOTA $^{1}$ \\ ${ }^{1}$ NemaLab-ICAM, Departamento de Biologia, Universidade de Évora, 7002-554 Évora, Portugal, \\ *E-mail:vmrv@uevora.pt; ${ }^{2}$ Lab. Microbiologia do Solo-ICAM, Departamento de Biologia, \\ Universidade de Évora, 7002-554 Évora, Portugal
}

\begin{abstract}
Summary
Until recently, the only entomopathogenic nematode (EPN) species reported from continental Portugal, was of the genus Steinernema. Following a national survey of EPNs in continental Portugal, several natural and managed habitats have been surveyed in the southern part of the country. From 57 soil samples collected using the Galleria mellonella trapping method, three samples yielded EPN. Morphological characterization and sequence analysis of the ITS regions of ribosomal DNA allowed the identification of EPN isolates as Heterorhabditis bacteriophora, representing the first report of this genus for continental Portugal.
\end{abstract}

Key words: Heterorhabditis bacteriophora; entomopathogenic nematode; Portugal

\section{Introduction}

The recognition of entomopathogenic nematodes (EPN) as successful biological agents in controlling important insect pests has promoted current knowledge on species biodiversity and their distribution within distinct geographical areas. These species belong to the families Steinernematidae Chitwood \& Chitwood, 1937 and Heterorhabditidae Poinar, 1976. Although obligatory insect parasites, these nematodes are capable of exploiting a wide range of soil habitats, such as cultivated fields, grasslands, dry areas, forests or ocean beaches and because of that they are widely distributed throughout the world (Hominick, 2002).

The presence and distribution of EPNs in continental Portugal is poorly known. The first report of an EPN species was made recently (Valadas et al., 2007), with the detection of Steinernema feltiae (Filipjev, 1934) Wouts, Mráček, Gerdin \& Bedding, 1982 from the Alentejo and Tejo valley regions. Following the initial surveyed habitats (oak stands and rice paddies), other natural and managed habitats have been selected and surveyed in Alentejo, and extended to some areas of the Algarve.

\section{Material and methods}

Soil sampling and nematode isolation

A total of 57 soil samples were collected from different types of natural and cultivated habitats distributed within five different habitats (Table 1). Each composite sample (3 - 4 subsamples), with a final volume of $2 \mathrm{~L}$ of soil, was collected at a depth of $0-20 \mathrm{~cm}$ and randomly taken from an area of $200 \mathrm{~m}^{2}$. In order to obtain EPN from the soil, the Galleria mellonella L. (Lepidoptera: Pyralidae) trapping method (Bedding \& Akhurst, 1975) was used. After mixing the soil, a $1 \mathrm{~L}$ subsample was placed in a plastic pot (12 $\mathrm{cm}$ diameter and $15 \mathrm{~cm}$ depth), with 20 last instar larvae of G. mellonella. The pots were stored at $25{ }^{\circ} \mathrm{C}$, and after $6-$ 12 days, the dead G. mellonella larvae were collected and transferred to White traps (White, 1929). Every 3 - 4 days, dead larvae were removed from the soil. Harvested infective juveniles (IJ's) were stored in an incubator at $10{ }^{\circ} \mathrm{C}$ in distilled water.

\section{Molecular characterization}

For morphological observations, several specimens of each isolate were collected from dead G. mellonella, mounted in agar $2 \%$ with $0.01 \%$ sodium azide temporary slides, and observed with an Olympus BX-51 light microscope. For molecular analyses, a single adult pregnant female of each isolate was used to extract genomic DNA using the JETQUICK Tissue DNA Spin Kit (GENOMED). PCR reactions were performed to amplify the complete ITS (Internal Transcribed Spacer)-rDNA region, using the forward primer TW81 (5'-GTTTCCGTAGGTGAACC TGC-3') and the reverse primer AB28 (5'-ATATGCTTA AGTTCAGCGGGT-3') (Joyce et al., 1994). A $50 \mu \mathrm{L}$ PCR reaction was prepared with $20 \mu \mathrm{L}$ of extracted DNA, 2,5U 
Table 1. Surveyed areas: habitat from the different soil samples, positive to the presence of H. bacteriophora. (The number of samples with EPN specimens is shown in brackets).

\begin{tabular}{|c|c|c|c|}
\hline Habitats & Region & $\begin{array}{c}\text { Number of soil } \\
\text { samples }\end{array}$ & EPN's species \\
\hline Corn field & Alentejo & $5(1)$ & H. bacteriophora \\
\hline $\begin{array}{c}\text { Mediterranean grasslands ("esteva } \\
\text { and giesta") }\end{array}$ & Alentejo & $4(1)$ & H. bacteriophora \\
Algarve & 5 & H. bacteriophora \\
\hline Pinus pinea stand & Alentejo & $8(1)$ & - \\
\hline Algarve & 8 & - \\
\hline Olive trees field & Alentejo & 3 & - \\
\hline
\end{tabular}

Taq polymerase (BioPortugal), 1X reaction buffer, 1.25 $\mathrm{mM} \mathrm{MgCl} 2,200 \mu \mathrm{M}$ each dNTP and 16 pmol each primer. The amplification programme was: one cycle at $95^{\circ} \mathrm{C}$ for 3 min followed by 30 cycles at $95{ }^{\circ} \mathrm{C}$ for $1 \mathrm{~min} ; 65^{\circ} \mathrm{C} 1 \mathrm{~min}$ $30 \mathrm{sec}$; and $72{ }^{\circ} \mathrm{C} 2 \mathrm{~min}$. The last step was at $72{ }^{\circ} \mathrm{C}$ for 5 min. Products were run on $0.8 \%$ agarose gels with $0.5 \mathrm{X}$ TBE buffer. PCR products were purified using GFX PCR
DNA and Gel Band Purification Kit (Amersham Biosciences) following the manufacturer's instructions. PCR products were sequenced in both directions by a contract sequencer (Macrogen Inc). For sequencing reaction, the primers used were: TW81 and AB28, with two additional internal primers, 58P (5'-ACGAATTGCAGACGCTTAG3') (forward) and H58R (5'-GTGCGTTCAAAACTTC
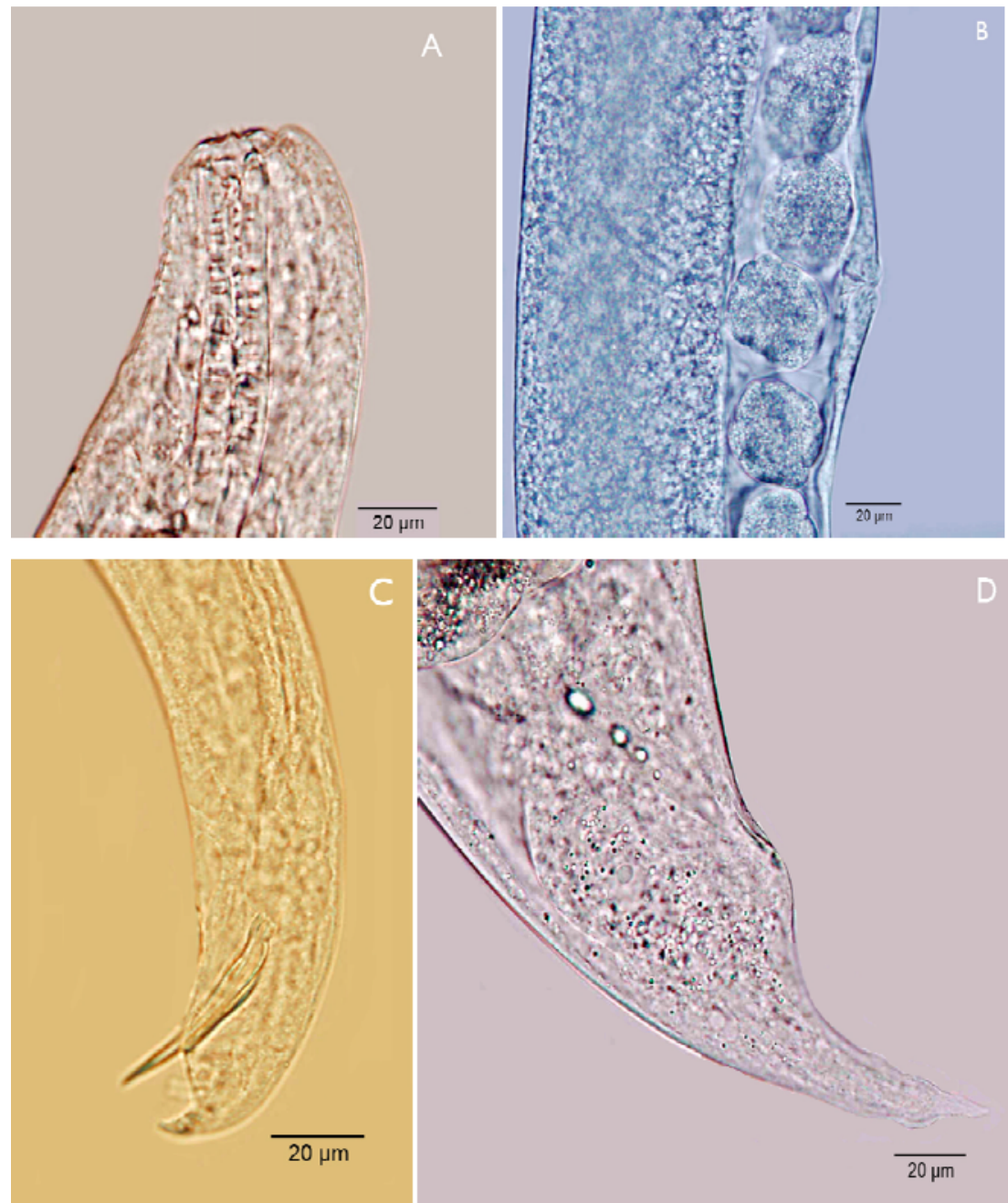

Fig. 1. Heterorhabdithis bacteriophora. A: Light micrograph (LM) of the anterior region of a hermaphroditic female. B: LM of vulval region. C: LM of male tail region. D: LM of female tail region 
ACC-3') (reverse) (Nguyen et al., 2004). Nucleotide sequences were analysed and edited using BioEdit Sequence Alignment Editor (version 7.0.4.1). The DNA sequences of the Portuguese isolates were compared with other sequences deposited in the GenBank database. Multiple alignments of the ITS rDNA sequences were obtained using Clustal W (Thompson et al., 1994). Phylogenetic analyses were performed by the Neighbour-Joining method, with bootstrap analysis based on 1000 resamplings using MEGA4 software (Tamura et al., 2007).

\section{Results and discussion}

EPNs were recovered from three samples from the Alentejo region, corresponding to three different sampled habitats (Table 1). The baited larvae infected from these samples displayed the typical red coloration, lack of putrefaction and retention of shape that is characteristic for G. mellonella cadavers infected with heterorhabditids. All the specimens found associated with the different sampled areas displayed the same main morphological characters (Fig. 1).
$H$. bacteriophora, the most geographically widespread species of this genus, is a common species in regions with continental and Mediterranean climates and it has been reported from different areas of Africa, Asia, Europe, and America (Hominick, 2002). In Southern Europe, this species has an abundant distribution, and it was found associated with several types of habitats in Northern Spain (Garcia del Pino and Palomo, 1996; Campos-Herrera et al., 2007) and in Southern France (Emelianoff et al., 2008). In the last case, two strains of $H$. bacteriophora were reported, based on small differences (4 nucleotides) in the ITS sequence, both strains being associated with the different types of sampled habitats (Emelianoff et al., 2008). Although several habitats with the same soil and climate characteristics as those in Southern France were sampled in Alentejo and the Algarve, only specimens belonging to one of the strains (strain 2) were found, and only in noncoastal habitats (Table 2) as reported in southern France (Emelianoff et al., 2008).

Based on the biodiversity and distribution of EPN's from the Iberian Peninsula and other Mediterranean regions, the presence of $H$. bacteriophora should be expected in conti-

Table 2. Positive samples: geographical region and characteristics from soil with $H$. bacteriophora

\begin{tabular}{|c|c|c|c|c|c|c|c|c|c|}
\hline Sample & \multirow{2}{*}{ Seasons } & \multicolumn{3}{|c|}{ Soil Characteristics } & \multicolumn{2}{c|}{ Geographic location } & \multicolumn{2}{c|}{ Atmospheric conditions } \\
\cline { 3 - 9 } & & PH & Texture & Total Nitrogen & Latitude & Longitude & Altitude & Tm anual ( ${ }^{\circ}$ C) & Pp (mm) \\
& & & & & & & & & \\
\hline I3 & Autumn & 6.58 & Medium & $0.2 \%$ & $38.77 \mathrm{~N}$ & $8.68 \mathrm{~W}$ & $77 \mathrm{~m}$ & 21.15 \\
\hline R7 & Winter & 6.35 & Medium & $0.2 \%$ & $37.34 \mathrm{~N}$ & $8.79 \mathrm{~W}$ & $90 \mathrm{~m}$ & 13.35 & 0 \\
\hline X7 & Spring & 5.48 & Coarse & $0.13 \%$ & $39.29 \mathrm{~N}$ & $7.46 \mathrm{~W}$ & $394 \mathrm{~m}$ & 7.65 & 0 \\
\hline
\end{tabular}

In the first generation, hermaphroditic females display a truncated head, with six well-developed conical lips (Fig. 1A), and median vulva without epiptygma (Fig. 1B). Second-generation amphimictic females are similar to the hermaphroditic females. Males displayed paired, separate spicules; bursa with nine pairs of papillae, a pair anterior to cloaca, two pairs adjacent to the spicules and six pairs distal to the anal opening, the latter six distributed in two sets of three (Fig. 1C).

The sequence flanked by the two primers yielded a total of $809 \mathrm{bp}$, composed of the partial 18S (nucleotides $1-14$ in the alignment), ITS1 (15 - 403), 5.8S gene (404 - 557), ITS2 (558 - 785), partial 28S (786 - 809). The ITS1-5.8SITS2 region of the three Portuguese isolates displayed 100 $\%$ similarity to each other [accession numbers EU435138 (isolate I3), EU435139 (isolate R7), EU435140 (isolate $\mathrm{X} 7)$ ]. BLAST searches suggested that the isolates belong to the species Heterorhabditis bacteriophora Poinar, 1976. Phylogenetic relationships based on the sequence alignment of the ITS rDNA region confirmed that the Portuguese isolates group with other isolates of $\mathrm{H}$. bacteriophora, when compared with other species of the genus (Fig. 2). nental Portugal. However, no species of this genus had been reported until now for continental Portugal, therefore this work represents the first report of the genus in this geographic area.

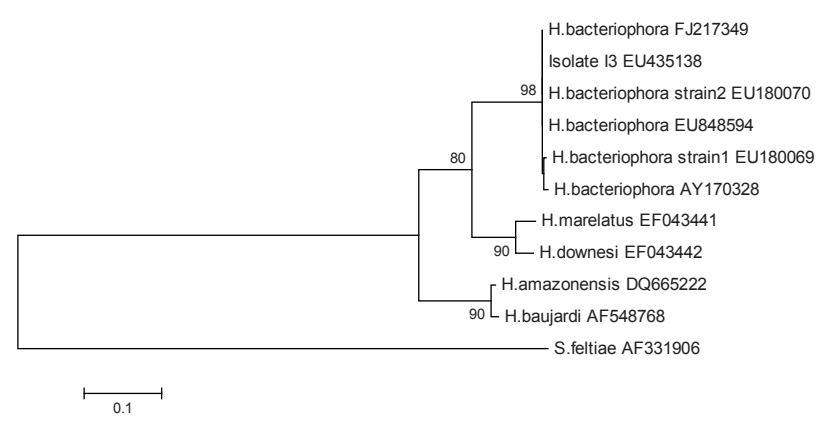

Fig. 2. Phylogenetic relationships of Heterorhabditis bacteriophora isolates from Portugal and other geographical regions, including other species of the genus, based on the sequence alignment of the ITS regions from ribosomal DNA. The dendrogram was generated by Neighbor-Joining analysis with 1000 bootstrap replication. Bootstrap values $(\%)$ are indicated at the nodes. The scale bar indicates $1 \%$ substitutions per site. 


\section{Acknowledgements}

The authors kindly thank Francisca Figo for technical assistance. This communication is a portion of the $\mathrm{PhD}$ dissertation of the first author, University of Évora, who is supported by a doctoral scholarship from Fundação para a Ciência e a Tecnologia (SFHR \BD\22086\2005).

\section{References}

AdAms, B. J., NGuYen, K. N. (2002): Taxonomy and systematics. In: GAUGLER, R. (Ed.). Entomopathogenic Nematology. Wallingford, UK, CABI Publishing, pp. $1-33$

Bedding, R. A., Akhurst, R. J. (1975): A simple technique for the detection of insect parasitic rhabditid nematodes in soil. Nematologica, 21: $109-110$

CAmpos-Herrera, R., Escuer, M., Labrador, S., Robertson, L., BArrios, L., GutiÉrRez, C. (2007): Distribution of the entomopathogenic nematodes from La Rioja (Northern Spain). J. Invertebr. Pathol., 95: 125 - 139 Emelianoff, V. Le Brun, N., Pagés, S., Stock, P., TAilliez, P., Moulia, C., SiCARD, M. (2008): Isolation and identification of entomopathogenic nematodes and their symbiotic bacteria from Hérault and Gard (Southern France). J. Invertebr. Pathol., 98: 211 - 217

HOMINICK, W. M. (2002): Biogeography. In: GAUGLER, R.
(Ed.), Entomopathogenic Nematology. Wallingford, UK, CABI Publishing, pp. 115 - 143

Joyce, S. A., ReID, A., Driver, F. Curran, J. (1994): Application of polymerase chain reaction (PCR) methods to identification of entomogenic nematodes. In: BURNELL. A. M., Ehlers, R. U., MASSON, J. P. (Eds), Biotechnology: Genetic of entomopathogenic nematode-bacterium complex. European Commission, Luxembourg, DG XII., pp. $178-187$

Garcia Del PinO, F., Palomo, A. (1996): Natural occurrence of entomopathogenic nematodes (Rhabditida: Steinernematidae and Heterorhabditidae) in Spanish soils. $J$. Invertebr. Pathol., 68: $84-90$

Thompson, J. D., Higgins, D. G., Gibson, T. J. (1994): Clustal W: Improving the sensitivity of progressive multiple sequence. Nucleic Acids Res., 22: 4673 - 80

Tamura, K., Dudley, J., Nei, M., Kumar, S. (2007): MEGA4: Molecular Evolutionary Genetics Analysis (MEGA) Software Version 4.0. Mol. Biol. Evol., 24: 1596 $-1599$

Valadas, V., Boyle, S., Vieira, P., Kakouli-Duarte, T., MotA, M. (2007): First report of an entomopathogenic nematode from continental Portugal. Helminthologia, 44: $226-229$

White, G. F. (1929): A method for obtaining infective nematode larvae from cultures. Science, 66: $302-303$ 